\title{
AKTUALIZÁCIA ROMÁNU ANNA KARENINOVÁ V SERIÁLOVEJ PODOBE
}

\section{Updating of Novel Anna Karenina in Serial Form}

Keywords: novel, serial adaptation, Anna Karenina, updating, The Beautiful Lie

Contact: Univerzita Pavla Jozefa Šafárika v Košiciach; gabi.homolova@gmail.com

Ked' nazrieme do histórie svetovej kinematografie, nájdeme v nej viacero filmových adaptácií toho istého textu. Medzi ne patrí aj román Leva Nikolajeviča Tolstého - Anna Kareninová, ktorý poslúžil ako predloha pre viac než dve desiatky filmových a seriálovách adaptácií. Príspevok sa zameriava na jednu z jeho najnovších adaptácií austrálsky seriál The Beautiful Lie (réžia: Glendyn Ivin) z roku 2015. Tolstého príbeh v tomto prípade nie je situovaný v Rusku, ani neponúka pohl'ad na spoločnost' v 19. storočí. Tvorcovia seriálu využili aktualizáciu a s ciel'om zachovat' základné motívy prototextu sa rozhodli presunút' dej do súčasnosti.

\section{Prístupy k adaptáciám}

Adaptácie sú niekedy prirovnávané $\mathrm{k}$ prekladom. Ako však potvrdzuje Linda Hutcheonová (Hutcheonová 2012: 31): „Rovnako ako neexistuje doslovný preklad, nemôže byt' ani doslovná adaptácia.“ V prípade filmovej adaptácie preto súhlasíme s tvrdením Jána S. Sabola (Sabol 2014: 9), ktorý hovorí „o miere preberania literárnych prvkov z konkrétneho literárneho textu textom filmovým. “ Adaptované dielo sa vždy nachádza na rozhraní medzi prototextom a metatextom a na jeho tvorbe sa podiel'ajú dva hlavné princípy: „tvorivý a reprodukujúci“ (Žilka 2006: 38). V závislosti od využitia konkrétneho spôsobu transformácie literárneho diela do filmovej podoby najčastejšie rozlišujeme tri základné typy adaptácií, ktoré vyčleňujeme na základe vzt’ahu k pôvodnému dielu - adaptácie verné predlohe, adaptácie s tvorivým vkladom scenáristu a vol'né adaptácie, resp. adaptácie na motívy (Aujezdský 2009: 13).

Existuje niekol'ko triadických modelov, ktoré spomenuté typy adaptácií pomenúvajú odlišnými termínmi, pričom ich význam zodpovedá ostatným deleniam. 
Alicja Helmanová (Helmanová 2005: 134-135) uvádza vedl'a seba niekol'ko delení od známych autorov: Geoffrey Wagner (1975) rozlišuje transpozíciu, komentár a analógiu, Michael Klein a Gillian Parkerová (1981) vyčleňujú adaptácie verné príbehu, adaptácie zachovávajúce iba základnú kostru príbehu a adaptácie zaobchádzajúce s originálom ako so surovým materiálom, ktorý predstavuje východisko pre vytvorenie odlišného diela. Triadický model taktiež ponúka Dudley Andrew (1984), ktorý pracuje s termínmi výpožička, transformácia a križenie. Sabol (Sabol 2014: 30) poukazuje aj na trojčlenné delenie Ivana Stadtruckera (1990), ktorý pracuje s termínmi transkripcia, analógia a improvizácia. Niektorí autori delia adaptácie nie na tri, ale iba na dva typy. Dyadický model ponúka napríklad Brian McFarlane (1996), ktorý rozoznáva transfer a vlastnú adaptáciu a Julie Sandersová (2006), ktorá pri vymedzení adaptácií rozlišuje adaptáciu a prisvojenie. Zatial' čo transfer a adaptácia disponujú znakmi odkazujúcimi na prototext, pri vlastnej adaptácii či prisvojení je náročné zistit' spojenie s iným textom. Prikláňame sa k názoru Pavla Aujezdského (Aujezdský 2009: 13), ktorý tvrdí, že v praxi medzi týmito typmi adaptácií nie je možné vymedzit' úplne presné hranice.

Ďalší priestor na analýzu ponúkajú adaptácie, ktoré predstavujú opätovné stvárnenie pôvodného textu - tzv. remake. Rusnák (Rusnák 2010: 205) ho definuje ako špecifický typ reinterpretácie diela $\mathrm{v}$ elektronických médiách, najmä v prostredí filmu. Ide o novú verziu úspešného filmového diela, pričom v niektorých prípadoch sa jeho tvorcovia rozhodnú priblížit' dielo súčasným divákom využitím aktualizácie. Aktulizácia sa podl’a Vlašína (Vlašín 1977: 15) netýka iba formálnej stránky diela. Podl'a Pavisa (Pavis 2003: 26) môže prebiehat' na niekol'kých úrovniach, od jednoduchej modernizácie kostýmov po adaptáciu pre odlišné publikum v odlišnej spoločenskohistorickej situácii. Ako upozorňuje Žilka (Žilka 2006: 43) „Texty s dôrazom na aktualizáciu majú prítomnost' vyjadrenú priamo v téme. Obyčajne sa zakladajú na porušovaní vžitých noriem a konvenčnosti, resp. prehodnocovaní skutočnosti." Dôležitý pri aktualizácii je preto nielen vkus nového publika, ale aj súčasný kontext a vývoj spoločnosti. Napriek tomu, že sa mení časové zasadenie a rámec príbehu, nemení sa nosná fabula diela ani charakter vzt’ahov medzi postavami (Pavis 2003: 43).

\section{Filmové a seriálové adaptácie románu Anna Kareninová}

Vzhl'adom na počet adaptácií môžeme skonštatovat', že román Anna Kareninová patrí u režisérov medzi oblúbené diela. Prvýkrát sa na filmovom plátne objavil pod rovnomenným názvom už v roku 1911 (réžia: Maurice Maitre) a jeho najnovšiu filmovú adaptáciu predstavuje skrátená kinoverzia pôvodne osemdielneho seriálu Anna Kareninová s filmovým názvom Anna Kareninová. Príbeh Vronského (réžia: Karen 
Šachnazarov) z roku 2017. Medzitým sa stal predlohou pre približne dvadsat' fimov a seriálov, ktorých tvorcovia pristúpili k tomuto románu trojakým spôsobom. Bud' sa snažili o čo najvernejšie zachovanie príbehu oproti predlohe (ide napr. o filmové adaptácie z rokov 1935, 1967, 1997, 2012, 2013), alebo sa rozhodli o výraznejšie eliminovanie niektorej z dejových línií, ktorú nahradili novou (napr. v seriálovom spracovaní z roku 2017 nevystupuje vôbec postava Levina, avšak dej je posunutý o 30 rokov dopredu v čase rusko-japonskej vojny), prípadne využili aktualizáciu a preniesli celý príbeh do súčasnosti. Práve posledný uvedený prípad predstavuje austrálska seriálová adaptácia - The Beautiful Lie - Nádherná lož (Ide o vol’ný preklad názvu, ked’že seriál nebol predabovaný do slovenského ani českého jazyka.).

Ked’že seriálové adaptácie disponujú väčšími časovými možnost’ami ako filmové, ponúkajú režisérom väčší priestor na detailnejšie vykreslenie jednotlivých dejových línií a vzájomných vzt’ahov medzi postavami. Nami skúmaný seriál je rozdelený do šiestich približne 60 -minútových epizód, v ktorých pozorujeme tragédiu Anny v novodobej spoločnosti, pričom (v prípade, že poznáme prototext) registrujeme aj viacero motívov totožných so zdrojovým textom. Vzt'ah diváka, ktorý pozná predlohu adaptácie, je zložitý fenomén, ktorý opisuje aj Helmanová (Helmanová 2005: 139-143). Odhliadnuc od individuálnych rozdielov recepcie, sú recipienti adaptácie, ktorí poznajú predlohu ovplyvnení spoločnými determinantami. Predovšetkým disponujú vedomou, resp. nevedomou (v prípade, že divák čítal knihu v minulosti si nemusí uvedomovat', kol'ko vecí si pamätá) spomienkou na knihu. Na základe spomienok na literárnu predlohu sa divák dostáva do úplne odlišnej situácie ako divák, ktorý nemá skúsenost' s originálom. Recepcia filmu sa vytvára $\mathrm{v}$ čase a divák si buduje štruktúru celku postupne na základe epizód a vytvárajúcich sa vzt’ahov. V prípade, že divák čítal literárnu predlohu, už od začiatku disponuje celou štruktúrou prezentovaného diela a postupne sledované epizódy iba umiestňuje do vopred daného celku. Proces vytvárania a overovania hypotéz, ktorý sa deje $\mathrm{v}$ mysli diváka bez skúsenosti s predlohou, ktorý hypotézy koriguje v priebehu deja a skutočný význam si uvedomuje až v samotnom závere, prebieha pri divákovi, ktorý má skúsenost' s originálom, odlišne. Divák na základe predchádzajúcej znalosti sleduje adaptáciu, pozná napríklad riešenie záhady, prípadne nepravú identitu postáv. Pocit, že štruktúru príbehu pozná, zotrváva aj $\mathrm{v}$ prípade, že režisér jednotlivé udalosti predstaví v inom poradí, prípade pristúpi k výrazným zmenám. Spomienka na originál stále vystupuje ako referenčný rámec, preto automaticky pristupuje ku komparácii. Kladieme si otázku, či je vhodné nazerat' na adaptáciu, v ktorej využil režisér aktualizáciu, iba z hl'adiska kritiky vernosti, teda poukázaním na rozdiely medzi prototextom a metatextom. 


\section{Ako sa pozerat' na adaptáciu The Beatiful Lie}

Svojím názvom žiadnym spôsobom nenaznačuje priamu spojitost's románom Anna Kareninová. Informáciu, že ide o adaptáciu románu L. N. Tolstého nedostane divák ani v úvodných či záverečných titulkoch. Pozrime sa bližšie na niekol'ko analógií medzi protextom a metatextom.

Začnime menami, ked’že tie ako prvé môžu divákovi naznačit', že sa s nimi už stretol v inom kontexte. Krstné mená hlavných postáv zostali vo väčšine prípadov bud' nezmené, prípadne boli skrátené, ale stále naznačujúce svojitost' s pôvodným menom, alebo úplne modifikované. Pre lepší prehl'ad ich uvádzame v tabul'ke.

\begin{tabular}{|l|l|}
\hline \multicolumn{2}{|c|}{ POMENOVANIE POSTÁV } \\
\hline ROMÁN & SERIÁL \\
\hline Anna Arkadievna Kareninová & Anna Ivin \\
\hline Alexej Alexandrovič Karenin & Xander Ivin \\
\hline $\begin{array}{l}\text { Sergej „Serioža“ Alexandrovič } \\
\text { Karenin }\end{array}$ & Kasper Ivin \\
\hline Alexej Kirillovič Vronskij & Skeet Du Pont \\
\hline $\begin{array}{l}\text { Katerina „Kitty“ Alexandrovna } \\
\text { Ščrbacká }\end{array}$ & $\begin{array}{l}\text { Kitty } \\
\text { Ballantyne }\end{array}$ \\
\hline Stepan „Stiva“ Arkad’jič Oblonskij & $\begin{array}{l}\text { Kingsley } \\
\text { Faraday }\end{array}$ \\
\hline $\begin{array}{l}\text { Daria „Dolly“ Alexandrovna } \\
\text { Oblonská }\end{array}$ & Dolly Faraday \\
\hline Konstantin Dmitrič Levin & Peter Levin \\
\hline Nikolaj Dmitrič Levin & Nick Levin \\
\hline
\end{tabular}

Rovnako ako v origináli aj seriáli je hlavnou témou dysfunkčnost' rodiny, ktorej príčinou je nevera. Tvorcom sa podarilo poukázat' na rozdielne spoločenské postavenie 
v spoločnosti, aj ked' sa dej neodohráva v Rusku v 2. polovici 19. storočia, ale v 21. storočí v Austrálii. Anna Ivin (Sarah Snook) a jej manžel Xander (Rodger Corser) predstavujú ,športovú šl'achtu“ ako bývalí hráči tenisu, ktorý je aj v súčasnosti často označovaný ako „,biely šport“, kedysi prezentovaný ako šport pre vyššiu spoločenskú vrstvu. Podobne aktualizovaný je aj spoločenský status Vronského, v tomto prípade Skeeta (Benedict Samuel), prostredníctvom novodobej profesie, ktorá určitým spôsobom korešponduje s lukratívnym povolaním vojenského dôstojníka v prototexte. V seriáli pracuje ako nezávislý hudobný producent. Život všetkých postáv a rodín je zasadený do modernej spoločnosti, v ktorej má Anna na prvý pohl'ad dokonalý život (má milujúceho manžela, diet’a, vysoký životný štandard). Táto dokonalost' sa však postupne javí iba ako ilúzia, ako nádherná lož. Aj v tomto spracovaní je zobrazený príbeh d'alších dvoch párov a ich (ne)št’astia v láske - brata Anny Kingsleyho a jeho manželky Dolly, a bývalej snúbenice Skeeta - Kitty a jej priatel’a Petra Levina žijúceho na farme. Vzt'ahy medzi spomenutými postavami sú vo vel'kej miere zachované, nájdeme medzi nimi iba niekol'ko odlišností (napr. rodičia Kitty nie sú nadšení zo zásnub Kitty a Skeeta, Skeet nepozná Kingsleyho pri vyzdvihnutí Anny na letisku a pod.), ktoré ovplyvňujú prítomnost' pôvodných motívov minimálne, ba vôbec. Ak sa pozrieme spät' na predlohu, súhlasíme s Paštekom (Pašteka 2005: 138), ktorý upozorňuje, že „,keby sme aspoň v hlavných črtách zrekapitulovali pohyby jednotlivých osôb na dejovej rovine románu, videli by sme, že ich prvotnou príčinou vo väčšej alebo menšej miere vždy bola Anna Kareninová... Iba medzi Annou a Levinom niet priameho vzt'ahu, na jeho životné osudy vplýva len okl'ukou.“ Osobne sa tieto dve postavy stretávajú takmer na konci románu, v 7. časti, v ktorej Anna zomiera. Čitatel’ románu, ak vníma ako jedinú hlavnú postavu Annu, pozerá sa na životy ostatných skrz ňu, avšak môže sa sústredit' napr. viac na líniu zobrazujúcu život Levina. V prípade seriálu je Anna ovel’a explicitnejšie naznačená ako ústredná postava. Nielenže je hybnou silou udalostí, ktoré ovplyvnia životy ostatných, ale je sama rozprávačom. Už na začiatku prvej epizódy informuje diváka o svojom konci: „Milovala som ho. Presvedčil ma, že dokážem prežit' čokol'vek. Ale mýlil sa. Kým môj chlapec bude mat' 7, ja budem mŕtva.“ (vol'ný preklad) Rovnako začiatok prvej a koniec poslednej epizódy rámcuje takmer identickým citátom o láske, ktorá ,je ako l’udia - narodí sa, rastie, mení sa, roky lásky, zomiera. Niektorá láska presiahne život. Láska je cudzia i dôverne známa, môže byt' zničená a napravená, láska môže byt’ stratená a potom znova nájdená. Láska je taká, akú si ju urobíte.“ (vol’ný preklad). Motív lásky vo všetkých jej obmenách je prítomný v seriáli celú dobu. Podobne ako je opísaná v uvedenom citáte, môžeme pozorovat' všetky jej spomenuté fázy medzi postavami. Okrem partnerskej lásky je zakomponovaná aj láska rodičov a detí. J. Honzík (Honzík 2000: 142) považuje za vrcholné pasáže, v ktorých vystupuje Anna „ples, kde okouzlila Vronského, setkání 
s Vronským u vlaku, dostihy, popis Annina roztěkaného stavu a pocitů rozdvojení po přiznání muži a zejména předsmrtné kapitoly.“ Takmer v každej adaptácii, ktorá sa snažila čo najviac pridržat' predlohy, nájdeme všetky vyššie uvedené scény, ku ktorým by sme zaradili ešte prvé stretnutie Vronského a Anny na vlakovej stanici v Moskve. V seriáli sú tieto scény aktualizované. Anna cestuje za bratom letecky a Skeetovu matku stretáva na palube lietadla. Scéna, v ktorej zomiera pracovník na železničnej stanici, bola inovovaná, avšak prvé znamenie smrti nachádzame aj tu (zomiera taxikár pred letiskom). Ples v Tolstého diele korešponduje zo zásnubným večierkom Kitty a Skeeta, kde Skeet venuje všetku svoju pozornost’ Anne. Prvého spoločného tanca sa síce divák nedočká, ale udalost', ktorá spustí ret’az následkov, prichádza už v ten večer. Napriek tomu, že Anna stretla Skeeta tretíkrát vo svojom živote, rozhodne sa s ním sexuálne zblížit'. Musíme podotknút', že sexualita je v seriáli prítomná po celú dobu, čo v Tolstého diele nenájdeme. Ako uvádza Pašteka (Pašteka 2005: 142) Tolstého ciel'om bolo „zobrazit' lásku ako cit alebo ako vášeň vo všetkých jej psychologických, morálnych, sociálnych dôsledkoch ... lásku podáva nie samu osebe, ale vždy cez problémy manželstva a rodiny.“

V seriáli nenachádzame obdobie dvorenia a presviedčania Anny, ktoré v románe trvalo takmer rok. Od prvého stretnutia na letisku po zásnubný večierok uplynuli dva týždne a od tohto večera môžeme hovorit' o nevere (záver 1. epizódy). Relatívne rýchle rozhodnutie podviest' svojho manžela by sme mohli pripísat' aj zmenám v spoločnosti za posledné storočie. Annin manžel je na rozdiel od knižného Karenina prítažlivý muž, ktorý má rád svoju rodinu, a tak je pre diváka t’ažké súcitit's Annou, ktorá sa ho rozhodla opustit'. V seriálovom spracovaní nachádzame viacero scén, ktoré sú aktualizované, ale ich myšlienka zostáva rovnaká. Scéna s dostihmi je párty v 2. epizóde, na ktorej sa prezradí Annin románik, ked' ju v putách spoločne so Skeetom odprevádza polícia. Ked' sa nakoniec dostane domov a Xander sa jej priamo opýta, či spí so Skeetom a Anna mu to potvrdí, jeho prvá reakcia súvisí s okolím, čo si pomyslia l'udia a čo napíšu médiá. Ďalej by sme mohli menovat' scénu po pôrode, návrat domov a opätovné opustenie syna. Dejová línia opisujúca život Kitty a Petra beží paralelne s Anninou a navzájom sú čoraz vo väčšom kontraste, ktorý vrcholí na svadbe Kitty (5. epizóda), kde sa objaví Anna ako jediná v červených šatách, pričom všetci ostatní sú v bielom. Anna upúta celú pozornost' na seba (analógia s divadlom $\mathrm{v}$ románe) a jej nešt'astie sa stupňuje tak, že ako jediné východisko vidí smrt'.

Toto moderné prevedenie Tolstého románu ponúka pohl'ad nielen na nešt'astnú lásku vydatej ženy, ale poukazuje aj na niektoré normy v spoločnosti, ktoré sa nezmenili za posledných 150 rokov. Román vykresl'uje postavy skrz ich činy a dialógy, divák, ktorý nemá skúsenost' s predlohou, vd’aka hereckému výkonu nadobúda pocit, že sa 
hlavná postava naozaj zamilovala do Skeeta, pozoruje ako opúšt’a rodinu a vidí následky jej rozhodnutia. Režisérovi sa podarilo Tolstého nadčasové rozprávanie preniest' do dnešnej doby ako plnohodnotné dielo. Myslíme si, že k takémuto typu adaptácii by sme nemali pristupovat' iba na základe „kritiky vernosti“, ale je vhodnejšie naň nazerat’ v prvom rade ako samostatné dielo a až potom ako na adaptáciu.

\section{Summary}

The paper deals with novels that have been adapted several times. One of them is novel Anna Karenina by L. N. Tolstoy. Some adaptationers tried to keep the original plot, others used the adaptation method - updating. The papers focus on australian serial adaptation named The Beautiful Lie, which was created in 2015. In this case the story was transfered into the 21 st century. We think about how to approach to this type of adaptation. We suggest judge this adaptation in the first place as a new film and than in the second place as an adaptation, because only looking for differences between novel and updating adaptation not has to bring relevanted results.

\section{Literatúra}

Aujezdský, P. Od knižky k televíznímu filmu. Brno: Janáčkova akademie múzických umění v Brně, 2009.

Ivin, G. The Beautiful lie. Televízny seriál z roku 2015. Austrália: ABC, 2017. Dostupné z: https://www.dailymotion.com/us.

Helmanová, A. Filmové adaptacie literárních děl. In: Tvořivé zrady: současné polské myšlení o filmu a audiovizuálni kultuře. Praha: Národní filmový archiv, 2005, s. $133-144$.

Honzík, J. Dvě století ruské literatury. Praha: Torst, 2000.

Hutcheonová, L. Teória adaptácie. Brno: Janáčkova akademie múzických umění v Brně, 2012.

Pavis, P. Divadelní slovnik. Praha: Divadelní ústav, 2003.

Pašteka, J. Svet literatúry, literatúra sveta. Analýzy a interpretácie II. zväzok. Bratislava: Petrus Publishers, 2005.

Pišút, M. et al. Dejiny svetovej literatúry 2. Bratislava: Osveta, 1963.

Rusnák, J. et al. Texty elektronických médii: Stručný výkladový slovník. Prešov: Prešovská univerzita v Prešove, 2010. 
Sabol, J. S. Medzi literatúrou, filmom a divadlom. Košice: Univerzita Pavla Jozefa Šafárika v Košiciach, 2014.

Tolstoj, L. N. Anna Kareninová. Preklad N. Szabová. Bratislava: Slovart, 2019.

Vlašín, Š. et al. Slovník literární teorie. Praha: Československý spisovatel, 1977.

Žilka, T. Vademecum poetiky. Nitra: Univerzita Konštantína Filozofa v Nitre, 2006.

The article is accessible in open access mode under licence CC BY-NC-ND Creative Commons Attribution-NonCommercial-NoDerivatives 4.0 